\title{
Local Government E-Procurement Practices in Indonesia: Accountability, Efficiency, and Barriers
}

\author{
Rachmat Hidayat \\ University of Jember, Jember, Indonesia \\ Charles Darwin University, Darwin, Australia
}

\begin{abstract}
E-procurement (electronic auctions) aims to cut the chain of bureaucracy and make public sector spending more effective and efficient. This paper discusses the implementation process of e-procurement in four regencies in East Java: Sampang, Kediri, Surabaya, and Jember with emphasis on the accountability and efficiency issues. There are two main aspects to the process of implementing e-procurement that hampered e-procurement acceleration and raised the potential for corruption in the process of implementing e-procurement: the user (end user of e-procurement) and the mediator [Procurement Services Unit-Unit Layanan Pengadaan (ULP) of each government institution]. These two elements play a crucial part in the process of e-procurement that is accountable, efficient, transparent, and fair. This paper suggests three points for improving the current practice of e-procurement in Indonesia: first, creating indicators/criteria of transparency and accountability in the internal e-procurement implementator; second, injecting the value and the importance of leadership and personal integrity; third, it needs to reformulate a new system of e-government that compatible or supporting e-procurement; fourth, increasing the role of the government monitoring unit.
\end{abstract}

Keywords: e-procurement, East Java, accountability, local government

E-government is not a new concept in the governance sphere. Nowadays, almost all regencies in Indonesia have applied e-government. It is not only a medium for development and information, but it also acts as a means to communicate with the community. Similar to the usage of the internet by the private sector, e-government brings a change in the process of goods and services. By the use of e-procurement, goods and public service can be delivered more effectively and efficiently, as well as reducing government spending. The use of e-procurement in public service shows transparency, which is relevant with the objective of the Indonesian Government. Indeed, President Policy (PP) 80/2003 in its fourth change to PP 8/2006 did not regulate and organize the application of e-procurement, yet at the present time, local government makes use of it in the public service sector. Although offering several positive developments, the application of e-procurement in Malaysia has shown that issues such as accountability, transparency, corruption, integrity, and cronyism still exist in the e-procurement system in Malaysia (Hui, Othman, Omar, Rahman, \& Haron, 2011). Data published in 2011 by the Indonesian Government Goods and Services Procurement Organization [Lembaga Kebijakan Pengadaan Barang dan Jasa Pemerintah (LKPP)] states that at present, there are 34

Corresponding author: Rachmat Hidayat, Ph.D. candidate, School of Business, Charles Darwin University, Australia, lecturer, Public Administration Department, Faculty of Social and Political Science, University of Jember, Indonesia; research fields: decentralization, public finance, and public sector management. E-mail: rachmat.hidayat@cdu.edu.au. 
regencies in 33 provinces in Indonesia which used e-procurement in government goods and service bidding. These studies will discuss several factors of e-procurement that act in supporting and accelerating roles. Furthermore, the process of implementation of e-procurement in four regencies of East Java (Sampang, Kediri, Surabaya, and Jember) will be discussed.

\section{E-Procurement and Its Relation With Three Actors of Good Governance}

E-procurement is not a new thing. It is usually associated with e-tendering or e-bidding which are commonly used in government institutions. According to Indrajit (2003), e-procurement is a present time purchasing mechanism or modern purchasing technique which makes use of internet based applications and other related information technology as enablers in the process. The e-procurement system is a set of related components or entities in the company which can be used to run the e-procurement concept in the company. Those related components are: hardware, software, human resources and the users, policy, governance, process, and the company's infrastructure. Hence, it can be said that e-procurement is good/service procurement done by the government through internet based electronic media (information technology and telecommunication) with the related components in the process. These components can be in the form of information technology, human resources, governance, and supporting policy.

\section{The Government Readiness Indicator}

A study conducted by Harvard JFK School of Government (Indrajit, 2006), shows that to implement the digitalization concepts in the public sector, there should be some readiness indicators. They are:

Support. The first and most important element that should be possessed by the government is the intention of the public and political official to implement the concept of e-procurement. Without "political will", it is not possible to do the development of e-procurement well. Hence, the following supporting factors are needed:

(1) There should be agreement on e-procurement development framework as one of the key points in aiming to the nation's vision and mission. It means there must be commitment to implement this policy;

(2) The e-procurement implementation needs rules which will support the policy so that it will have a strong law base. Therefore, local rules are necessary;

(3) Government should give public information access and transparency. The need of the society to get information should be facilitated by the local government so that they can use any possible information access channel;

(4) The concept of e-procurement should be introduced to the official and the business society through many sympathetic campaigns.

Capacity. What is meant by this second element is the availability of ability or capability of the local government in implementing e-procurement. The minimum requirements of the government are:

(1) Availability of information technology infrastructure;

(2) Availability of human personnel with the competency and expertise which are needed so that the implementation can be done smoothly;

(3) Availability of an organization which can handle the e-procurement system.

\section{The Business Society Readiness Indicator}

For implementing e-procurement, it is equally important to pay attention to business itself as a bidding 
partner. The business society should also possess readiness to do the good/service procurement process so that it can be done in accordance with the principles of good corporate governance, with special emphasis on the code of conduct. By possessing this attitude, deception and corruption can be avoided. Strengthening from inside the business association itself is also needed. The business association is not only treated as a gathering place for the members, but also as a code of conduct undertaker. Hence, it should be able to discipline the members who violate the code of conduct. The association should also take role as medium that stands between the government and the business community for socializing the rule and policy related with the good/service procurement activity. Therefore, the members of the association will truly understand the procedure and method used in the bidding process. The readiness of a bidding partner can also be seen from the use of information and communication technology in their company. This can be the indicator of the bidding partner's capability in joining the bidding process online. Another indicator is the opposition given by the aggrieved party, either alone or together with other parties if the bidding is proved to be wrongly administered wrongly.

\section{The Society Readiness Indicator}

Last but not least is the readiness of the society itself. The society should have active participation in the form of inclusion and involvement to implement e-procurement. Here are some indicators to show the society's readiness:

(1) E-literacy of the society. The society decision-maker on policy should understand how to use the internet to access information;

(2) The existence of a self-supporting institution [Non-Governmental Organization (NGO) or interest group] which pays good attention to the IT (information technology) development will play an important role;

(3) Availability of an IT education institution;

(4) Awareness of the society to make a report to the authority when there is an incident and any indication of corruption. The presence of such a report shows the existence of critics.

Figure 1 shows the electronic bidding mechanism in Indonesia. The process is preceded with the demand of the users in each ministry, organization, and local government (province/regency/city) to each Procurement Service Unit [Unit Layanan Pengadaan (ULP)]. The ULP then will input the data related with the good/service procurement to the Electronic Bidding System [Sistem Pengadaan Secara Elektronik (SPSE)] which is integrated with the Electronic Bidding Institution [Lembaga Pelelangan Secara Elektronik (LPSE)] in each ministry, organization, and local government (province/regency/city). LPSE as the regulator of the electronic bidding will be the IT based electronic interaction area between ULP and each vendor/provider. The electronic bidding process is organized by the PP No. 70 of 2012 which arrange the second change of PP No. 54 of 2010 about good/service procurement. Several important points regarding the organizational structure of good/service procurement include:

(1) Budget User (Pengguna Anggaran/PA)/Authority of Budget User (Kuasa Pengguna Anggaran/KPA);

(2) Commitment Maker Authority (Pejabat Pembuat Komitmen/PPK);

(3) Procurement Service Unit (ULP)/Procurement Authority;

(4) Job Receiver Committee/Authority. 


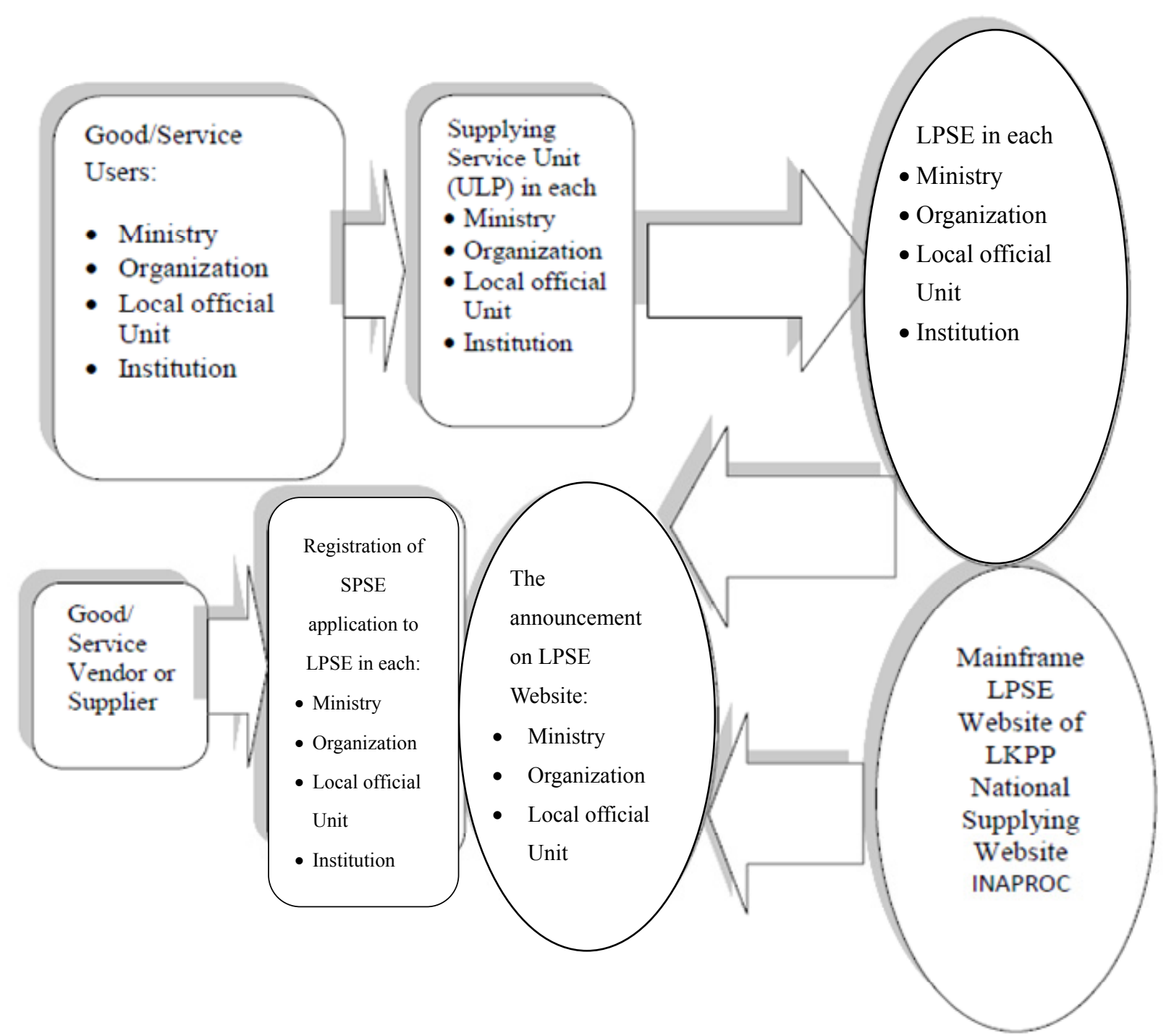

Figure 1. The process of and mechanism of e-procurement in Indonesia. Source: Hidayat and Suji (2012).

The duties of Budget User (PA) and KPA are as follows:

(1) Stating the procurement general plan;

(2) Announcing widely about the procurement general plan;

(3) Appointing Commitment Maker Authority (PPK);

(4) Appointing the Procurement Authority;

(5) Deciding the Job Receiver Committee/Authority;

(6) Deciding the gainer of the selection;

(7) Settling any disagreement between PPK and ULP;

(8) Making a financial report;

(9) Watching over the storage and maintenance of all the documents.

The duties of the Commitment Maker Authority (PPK) are:

(1) Establishing a list of self-estimation price [Harga Perkiraan Sendiri (HPS)];

(2) Signing the contract; 
(3) Controlling the contract implementation.

The Procurement Service Unit is organized with the following conditions:

(1) All ministry, organization, and institution should have ULP;

(2) ULP in each ministry, organization, and institution is formed by the minister, chairman of the organization, and the leader of the institution;

(3) The election process is done by working unit (Pokja);

(4) The number of members should be three (minimum);

(5) The under 50 million rupiahs contracts should be done by ULP or Procurement Authority;

(6) Deciding the winner.

The consultant provider is organized as follows:

General selection and simple selection. General selection with the announcement requirement:

(1) Website in ministry, organization, and institution with official announcement board;

(2) National procurement website;

(3) Short list of five to seven companies.

Simple selection with the announcement requirement as follows:

(1) An announcement in ministry, organization, and institution website and Official Announcement Board of the national procurement website;

(2) Short list of five to seven companies;

(3) The value is less than 200 million rupiahs.

Direct appointment with the following conditions. Pre-qualification process with one provider, criteria: immediate/cannot be delayed:

(1) Emergency handling;

(2) Concerning national defense;

(3) One consultant;

(4) A consultant who has a copyright.

Direct procurement with the following conditions.

(1) The value should be less than 50 million rupiahs;

(2) Done by one Procurement Authority.

Contest with the following conditions.

(1) Done with a certain implementation of idea, creativity, innovation, and method;

(2) Possess an unset price.

\section{E-Procurement Transparency and Accountability in Four Local Governments of East Java}

E-government development in Indonesia has reached a significant advance, as shown in the report E-government Survey 2012 released by United Nations (UN). In this report, Indonesia's position moves up 16 levels, from 109 in 2010 to 93 in 2011. Indonesia is also included in the list of nations with best performance, together with other 30 countries. This was achieved because during these several years, there was much optimal effort done by the Indonesian Government in utilizing the e-government in the public service. This was a huge advance achieved by the government, that is, the releasing of President Instruction No. 17/2011 in the end of 2011. This instruction obligated all Indonesian government institutions to use e-procurement, with a clear objective. The central government offices should use $75 \%$ of the allocated budget, while the local government 
offices only requires to use $40 \%$ from its budget to be spend by thorough the e-procurement. This is such an important breakthrough because in President Policy No. 54/2010, the minimum target on the application of e-procurement is not explicitly arranged. The lack of a speficic target can make the local government avoid implementing electronic auctions. The objective of procurement good/service electronically is to improve transparency and accountability, improve market access and healthy business competition, improve the procurement process efficiency level, support monitoring and audit process, and fulfill real time information access needed to realize clean and good government. Hence, not only is the implementation of e-procurement relevant with the reduction of corruption, but it can also be a "quick win" mechanism for the local government to guarantee the achievement of clean and good government. The local government budget is very large and susceptible in the process. Good procurement is a very high risk area where corruption can happen, that is why e-procurement can function as a means which can record the real time bidding process. E-procurement can ease the monitoring process and guarantee transparent accessibility for the public and business society. In East Java, there is a significant improvement on electronic bidding value, as said by the Deputy of Good/Service Procurement Policy and Strategy Development Sector, Himawan Adinegoro in a seminar on Government Good/Service Procurement Electronic System (Semiloka Sistem Elektronika Pengadaan Barang/Jasa Pemerintah) in Surabaya (Jawa Pos, September 28, 2012). He states that the value of e-procurement in East Java is 1.3 trillion rupiahs in September 2012 (see Table 1).

Himawan further states that the e-procurement implementation in East Java can be considered one of the best in Indonesia, though among 38 cities and regencies in East Java, there is only one region (Bangkalan) which has not performed online bidding. This study focuses on the package volume and the bidding value which is offered by Sampang, Kediri, Surabaya, and Jember through the LPSE website in each regency.

Table 2 vividly describes the recorded data on the LPSE website of Sampang until October 2012, shows that there is a balanced portion of local expense through LPSE website. This is relevant with the President Instruction No. 17/2011 which obliges all national institutions to implement e-procurement in central government. Kediri also shows an excellent trend in LPSE application which is done by LPSE of the regency, even though there was a transition from manual style bidding before. As one of the institutions with much experience in doing electronic bidding, Surabaya seems to implement the e-procurement application optimally. The deputy of ULP of Surabaya, Mr. Tri Broto states that what is important is "the political will" in implementing electronic bidding through LPSE Surabaya, so that it can be done well without intervention. While the recorded data on the LPSE website of Jember until October 2012, show a significant difference between expenses done electronically and non-electronically. The data show that Jember has done less electronic bidding, but with a quite significant value.

Table 1

The Value of Online Government Good/Service Procurement in East Java

\begin{tabular}{lll}
\hline No. & Year & Rupiahs \\
\hline 1 & 2010 & $700,000,000,000$ rupiahs \\
2 & 2011 & $1,300,000,000,000$ rupiahs \\
3 & $2012^{*}$ & $1,300,000,000,000$ rupiahs \\
\hline
\end{tabular}

Notes. ${ }^{*}$ until the middle of September; Source: Jawa Pos (September 28, 2012). 
Table 2

The Amount of E-Procurement Package Compare With the Regular Procurement Package

\begin{tabular}{llll}
\hline Regency & Year & E-procurement bidding package & Non e-procurement package \\
\hline \multirow{2}{*}{ Sampang } & 2012 & 108 & 262 \\
& 2013 & 367 & 1 \\
Kediri & 2012 & 123 & 13 \\
& 2013 & 220 & 0 \\
Jember & 2012 & 73 & 120 \\
& 2013 & 294 & 1 \\
Surabaya & 2012 & 393 & 0 \\
& 2013 & 908 & 0 \\
\hline
\end{tabular}

\section{E-Procurement and Local Government Budget}

Government Good/Service Procurement Policy Organization (LKPP) is a regulator and provider of mainframe websites for all Indonesian government institutions. Its position as a regulator can guarantee the e-procurement principles: efficient, effective, transparent, competitive, indiscriminate, open, and accountable. Data made by LKPP show that there are 315 LPSE in 32 provinces and 613 institutions in Indonesia. In 2012, there are about 24,475 bidding packages with the value more than 38 trillion rupiahs which use the e-procurement application. From these data, LKPP reportedly saved 4.4 trillion rupiahs worth of national financial efficiency. This efficiency comes from the cutting of transportation, accommodation, consolidation, and printing expenses. LKPP also acknowledges that there are $125 \mathrm{good} / \mathrm{service}$ vendors listed and verified officially in the SPSE system. This is consistent with the writer's finding in Pemkot Surabaya which confirms the positive performance of e-procurement implementation in cutting the government budget. The following data show the efficiency of the Surabaya budget after using the electronic bidding system.

Based on the data below, Surabaya achieved a budget saving after implementing e-procurement of up until 1.392 billion rupiahs since 2008 until September 2012, or saved the budget of $26.96 \%$ from the total 5.068 billion rupiahs. While in a recent budget until September 2012, Surabaya can save 207 billion rupiahs, or about $19.32 \%$ of the total budget of 1.340 zillion rupiahs. This shows that the implementation of e-procurement has a positive influence on the saving of state funds (see Table 3 ).

Table 3

E-Procurement Implementation and Efficiency in the City Surabaya

\begin{tabular}{llll}
\hline Year & Budget (in billion) & Efficiency (in billion) & Percentage $(\%)$ \\
\hline 2008 & 340 & 80 & 23.68 \\
2009 & 1,200 & 384 & 29.97 \\
2010 & 1,300 & 464 & 35.19 \\
2011 & 988 & 257 & 34.07 \\
2012 & 1,340 & 207 & 34.32 \\
$2013^{*}$ & 5,068 & 1,392 & 26.93 \\
\hline
\end{tabular}

Note. ${ }^{*}$ up to October. 


\section{The Challenges of E-Procurement Implementation in Four Regencies in East Java}

This study has successfully identified several challenges in East Java. There are two main aspects that could be an obstacle in the acceleration of e-procurement and could raise the potential of corruption in the e-procurement implementing process. They are the user factor, in this case, the user of goods/services; and the mediator aspect, that is the ULP in each related ministry, organization, and institution. In the user aspect, the identified challenges will be:

(1) The effort of Satuan Kerja Perangkat Daerah/SKPD (local government unit/institution) to bring out their stuff from ULP;

(2) The package proposal from SKPD to ULP which is out of schedule;

(3) When SKPD offers a technical specification, asking for a certain brand;

(4) The absence of SKPD in the meetings;

(5) The cancellation of a package due to insufficient planning;

(6) SKPD disqualifies the winner with an inappropriate reason.

These challenges can cause the following problems:

(1) The occurrence of corruption between SKPD with the vendor/partner;

(2) The occurrence of corruption between ULP and SKPD, which can be taken advantage of by vendor, politicians, and the related parties;

In the mediator aspect, the challenges are:

(1) Misleading information between ULP and LPSE due to the presence of ULP personnel in LPSE website;

(2) The performance of LPSE which is not maximum, since not all output has been done automatically;

(3) IT based management information system is not yet integrated in almost all local governments, except in Surabaya.

Those challenges will in return trigger the occurrence of the following deviations:

(1) Ineffective and inefficient system performance;

(2) A lengthy process of decision-making.

In brief, the above described the main problem identified by this study is that e-procurement implementation in Indonesia has not been able to maximize the role of ULP as the mediator in the e-procurement process. The fact that ULP is part of the local government is one of the aspects that may endanger the transparency and accountability of e-procurement. This study shows that it is necessary to make a strict differentiation between the mediator and user in the e-procurement process. If they are put together, there will be potential of deviation, administratively or politically.

The following figure will briefly explain about the challenges in the implementation of e-procurement in four regencies in East Java, Indonesia (see Figure 2). 


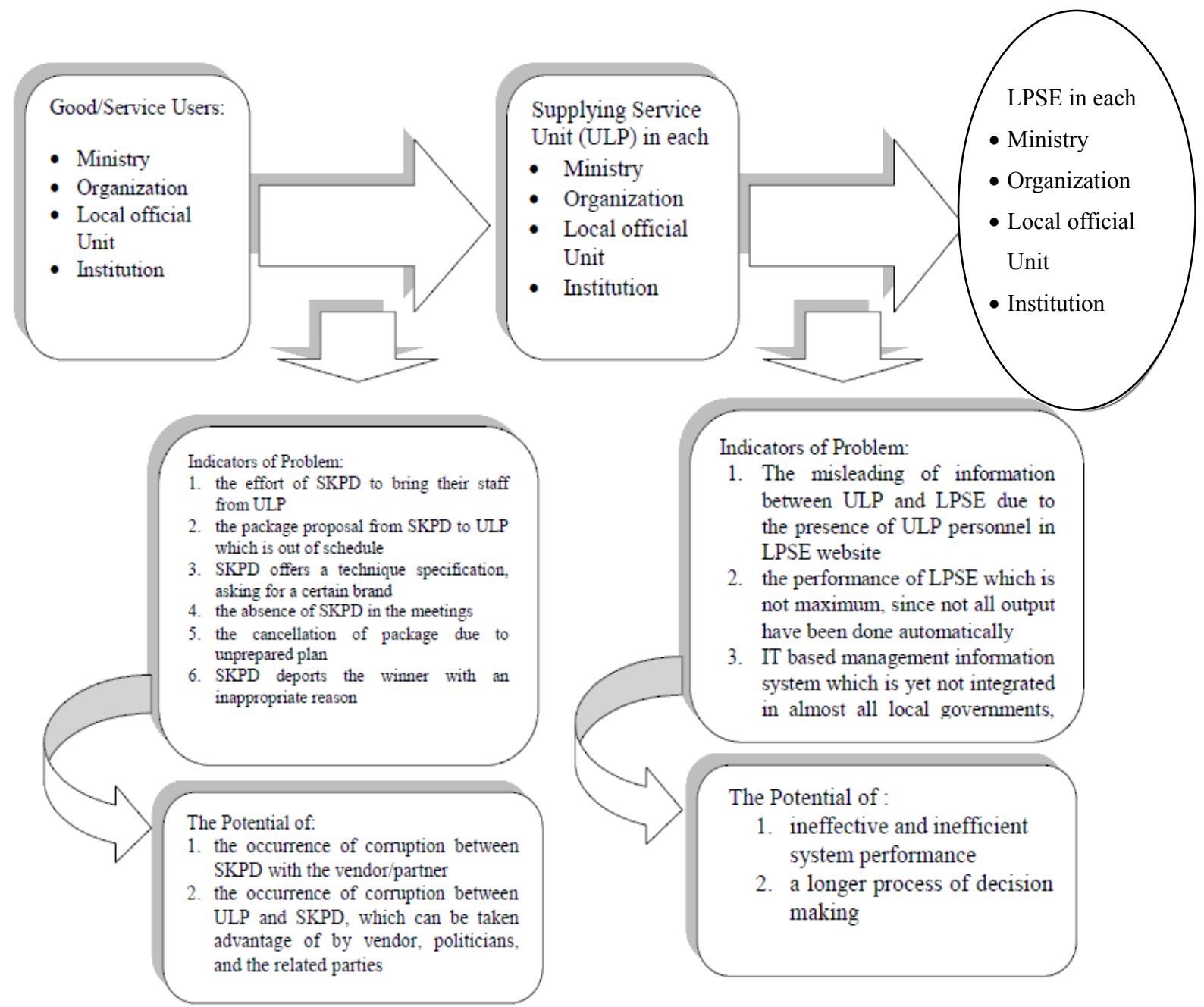

Figure 2. The challenges in the implementation of e-procurement in the four regions in East Java. Source: Hidayat and Suji (2012).

\section{Conclusions and Recommendations}

E-procurement is important in all aspects of government so that the bidding process will be more efficient, effective, and transparent. It will reduce expenses, corruption, and mis-allocation of public sources in the era of decentralization in Indonesia. This study shows how the implementation of e-procurement in four regencies in East Java (Sampang, Kediri, Surabaya, and Jember) has advanced in several ways, though there are also some challenges. These are:

(1) The unclear indicator of transparency and accountability in the procurement process;

(2) The low level of political commitment of the local government;

(3) The absence of the e-government system which is compatible with the central e-procurement mainframe;

(4) The weak internal monitoring by the central and local governments, which can be a crucial aspect in the implementation of transparent and accountable e-procurement.

Several recommendations on fostering the process and the implementation of e-procurement that endorse the principles of accountability and efficiency in Indonesia: 
(1) Creating indicators/criteria transparency and accountability in the internal e-procurement implementator:

(a) Not mentioning any specific brands or the specification of goods/services to be auctioned;

(b) Submission of procurement based on a predetermined rotation auction date;

(c) Periodic rotation ULP members to reduce the potential for fraud;

(d) The strict dichotomy between the committee of ULP.

(2) The importance of leadership and personal integrity:

(a) The enactment of internal integrity pact;

(b) The enactment of a sustainable performance monitoring unit in local government (ULP-LPSE);

(c) The need of political endorsement from the local political stakeholder.

(3) The need to reformulate a new system of e-government that compatible or supporting e-procurement:

(a) E-city planning;

(b) E-budgeting;

(c) E-project planning;

(d) E-procurement;

(e) E-sourcing;

(f) E-delivery;

(g) E-controlling;

(h) E-performance;

(i) E-asset.

(4) Increasing the role of government monitoring unit (inspectorate):

(a) Revitalizing the institutional monitoring of the implementation of the e-procurement;

(b) Revitalizing the institutional monitoring on the standard operating procedure of e-procurement;

(c) Revitalization on the institutional authority of ULP and LPSE.

\section{References}

City of Surabaya. (2012). Equipment unit report Surabaya city. Unpublished Reports. Surabaya.

Hidayat, R., \& Suji. (2012). National strategic research report: Accelerating e-procurement capability and regional business climate growth model-based e-gov.

Hui, W. S., Othman, R., Omar, N. H., Rahman, R. A., \& Haron, N. H. (2011). Procurement issues in Malaysia. International Journal of Public Sector Management, 24(6), 567-593.

Indonesian Ministry of Internal Affairs. (2004). Development of electronic government policy in the department of interior and local government. Jakarta.

Indrajit, R. E. (2006). Electronic government: Development strategy and development of public service system based digital technology. Yogyakarta: Andi.

Jawa Pos. (2012). The increased number of electronic auctions in East Java. Surabaya.

LPSE (Lembaga Pelelangan Secara Elektronik), Jember Regency Electronic Procurement Service. (2012). Bidding data (data file). Retrieved from http://lpse. jemberkab.go.id/eproc/app

LPSE (Lembaga Pelelangan Secara Elektronik), Kediri Regency Electronic Procurement Service. (2012). Bidding data (data file). Retrieved fromhttp://lpse. Kedirikab.go.id/eproc/app/service=page/home

LPSE (Lembaga Pelelangan Secara Elektronik), Sampang Regency Electronic Procurement Service. (2012). Bidding data (data file). Retrieved from http://lpse. Sampangkab.go.id

LPSE (Lembaga Pelelangan Secara Elektronik), Surabaya City Electronic Procurement Service. (2012). Bidding data (data file). Retrieved from http://lpse. surabaya.go.id/eproc/app

United Nation. (2012). E-government survey 2012. New York, United Nation. 